\title{
Communication Pathology: The Way In Africa*
}

\author{
René Hugo \\ Head: Department of Communication Pathology \\ University of Pretoria
}

\begin{abstract}
OPSOMMING
Universiteite in Suider-Afrika moet tans in diepte besin oor die transformasie wat nodig is om tersiêre onderrig van wêreldgehalte te verseker. In besonder, wat beroepsgerigte tersiêre programme betref, word dit al hoe belangriker dat antwoorde op vrae verkry word soos: is die akademiese uitsette van hoër onderrig relevant vir en verantwoordbaar in die kontehs van beroepsbeoefening? Wat die Departement Kommunikasiepatologie aan die Universiteit van Pretoria betref, is die pad duidelik: ' $n$ beroepsgerigte onderrigprogram wat leergeleenthede bied aan studente wat uiteindelik' $n$ diens aan' $n$ bepaalde deel van die bevolking moet lewer - diegene wat nie kan praat of hoor nie - moet die spesifieke aard van die gemeenskap wat bedien word as vertrekpunt gebruik vir enige langtermyn strategiese beplanning. Dié gemeenskap is ' $n$ Afrika-gemeenskap. Onderrigprogramme, navorsingsaktiwiteite en gemeenskapdienslewering sal derhalwe verafrikaniseer moet word.
\end{abstract}

\section{ABSTRACT}

Universities in Southern Africa are currently deeply involved in transformation processes in order to ensure world class tertiary education. More specifically in the case of vocationally oriented tertiary programmes, it has become necessary to provide answers to questions like: are the academic outcomes of higher education relevant to and accountable in the context of the workplace? For the Department of Communication Pathology at the University of Pretoria the answer is unequivocal - a programme that aims to provide learning opportunities for professionals who must eventually render a service to a specific population (the individual with a speech, voice; language or hearing disorder), should ensure that the characteristics of this population serve as the basis for strategic planning. This population is an African population. Educational programmes, research projects and community service must therefore be africanised.

KEY WORDS: South Africa, transformation, tertiary education,africanised

\section{INTRODUCTION}

Ex Africa semper aliquid novi. Out of Africa always something new. The emphasis on renewal currently forms a large part of the discussion surrounding the transformation of universities. One of the viewpoints which is most clearly stated is the call for universities to africanise. The rationale behind this is that africanisation is the only way to ensure that fundamental transformation, and not mere cosmetic reformation, will take place within the universities (Nigga, 1997).

This idea is not as new as its proponents would have us believe.

In 1922 Caseley Hayford, a West African, called for the institution of an 'Africa university' which would create an 'Africa ethos'. This request was stated even more dramatically by Dr Kwame Nkrumah: "We must in the development of our university bear in mind that once it has been planted on African soil, it must take root amidst African traditions and values" (in Sono, 1996:120).

This philosophical premise is often quoted in South

* This article is based on an inaugural address delivered on 8th October, 1998, University of Pretoria
Africa as part of the big debate about the transformation of tertiary institutions, with Prof Makgoba as the most prominent and best known proponent thereof. In 1992 a conference organised by the CUP came to the eventual conclusion that, although there is an urgent need for universities to africanise, the specific characteristics of such a process is still unclear..

In most academic debates it is often the terminology or concepts which cause the most uncertainty. This is also true in the africanisation debate and it is evident from the literature that it is easier to explain what africanisation does not entail, than to explain what it does.

- It is not the acquisition of black staff and students, irrespective of merit;

- It is not a lowering of standards;

- It is not the establishment of campuses where instigation, strikes and corruption are rampant.

According to Makgoba, the africanisation of universities implies the following: "... an African university should be one who's cultural and philosophical foundations are located within the African paradigm in its values and ethos. Like all traditional roles of a university it should pursue knowledge and social responsibility. It should strive 
for excellence and high standards of teaching, research and community service. Its curricula and culture should reflect the culture of Africa in its fullest sense, that is: diverse, vibrant, dynamic, accommodating and tolerant" (Makgoba, 1996:115). In essence, it is the establishment of a specific ethnocentric ethos as matrix within which tertiary education must take place.

It is important that the opposing premise should also be recognised. According to this, it is impossible to africanise any university, primarily because there is no entity that truly represents 'Africa'. How can one really characterise the nature of Africa? It is a continent that stretches from Cape to Cairo; it is three times the size of the USA; it comprises 53 diverse countries and houses approximately 700 million inhabitants. Furthermore the concept of africanisation is untenable because it is a philosophical absurdity. In the same sense it is impossible to 'anglicanise' Oxford or to 'americanise' Harvard. The core and essential nature of a university does not lie in the hands of an American, a Briton, or an African. It is the scientist, the academic, and their quest for knowledge, which forms the true core of any university. In this respect Sono explains: "Knowledge is universal, not parochial ... Knowledge cannot be kraaled or parcelled out in nationalistic terms ... All true knowledge makes people seek and embrace it without regard for its origins" (Sono, 1996:123).

\section{COMMUNICATION PATHOLOGY: THE SCIENCE AND THE PROFESSION}

The science of Communication Pathology can be described as the study of normal and abnormal human communication, including its development. Pienaar defined it as early as 1962 as: "Logopaedics studies the different abnormalities in the communication process ... a specialised medical auxiliary science which is indispensable in a modern habilitation programme, due to the dependence of the individual as a social being on his means of communication with other group members (Pienaar, 1962, in Cilliers, 1980:1).

Communication can broadly be subdivided into the components of reception (mainly through the auditory sense) and expression (mainly through speech and the voice). The system of symbols that is the foundation of both these components, is language. It is therefore logical that the two main professions related to pathological communication are that of speech-language therapy and audiology.

The latest document on a national curriculum for the profession, presented to the Professional Board for Speech-language Therapy and Audiology, provides the following definitions of the two professions:

- A speech- language therapist is a person who practices the science of communication pathology in order to make a difference in the lives of people with a speech, voice or language disorder; those with a disorder in the social and cognitive processes which are the foundation of such capabilities, and those with a disorder in the speech and/or language production system that has a negative effect on their communication.

- An audiologist is a person who practices the science of communication pathology in order to make a difference in the lives of people with a hearing loss, auditory processing disorders and/or those who experience difficulty communicating due to a loss of hearing.
Conservatively estimated, this population of persons with a communication disorder forms approximately $10 \%$ of the total population. It remains inconceivable that, despite this high occurrence, and with the exceptional emphasis that is placed on the importance of communication today, the role of communication pathology is still not sufficiently recognised.

In her inaugural address in 1993, my predecessor, Prof. Isabella Uys, discussed in sufficient detail the development of tertiary education in communication pathology since its initiation in South Africa in 1937. It is therefore not necessary to repeat these facts. However, within the theme of africanisation, it would indeed be worthwhile, to consider the development of this tertiary programme at the University of Pretoria more closely.

In 1959 Prof. $P$ de V Pienaar started the course in Logopaedics at Pretoria in the former Department of Speech Science and Speech Therapy. He established his undergraduate programme on a European foundation, based on his involvement with the French and German universities where he received his initial training. He was succeeded by Prof. Izak Hay, who had a strong technocratic influence from his engineering background, linked to the American model of professional practice, which he developed during his years of study at the Central Institute for the Deaf (CID) in Illinois. (It is interesting to note that it was probably Izak Hay who, although he was no rehabilitator himself, through his association with the CID, established a tradition at the University of Pretoria of oral communication for the hearing impaired.). On his retirement, he was succeeded by Prof. Uys. She also had an American orientation, but other than that was a great supporter of holism. As a result of this, the professional education of speech-language therapists and audiologists at UP was influenced as follows:

- Through Prof. Uys's efforts the Department of Communication Pathology moved closer to university structures, systems and standards, so that the Department could make a meaningful contribution within the broad tertiary system.

- Secondly, she realised the importance of professional transformation related to the demands of the South African community and made a special attempt to promote this amongst communication pathology clinicians (Uys, 1993).

Against this background, the logical question is - what should be the future of professional training in Communication Pathology at the University of Pretoria? As part of the transformation of universities, vocationally oriented programmes should urgently attempt to provide answers to questions such as the following: "Are academic outcomes of higher education provision relevant to and deliverable in the workplace setting?" (Seagraves et al, 1996:157). As far as the Department of Communication Pathology is concerned, the future principle is clear: a vocationally-oriented programme that educates students to deliver a service to a certain sector of the population - those that cannot speak or hear - should recognise that the specific nature of this community must serve as the basic point of departure for all their educational programmes. This community is an Africa community. Education will therefore have to be africanised.

The africanisation of educational programmes will af- 
fect the profession in two respects, namely:

Firstly, the existing Western model of service provision to the person with a communication disorder is one which is generally considered a luxury - available for the few that can afford it. This implies that a communication pathologist is trained to diagnose and treat patients on a one-to-one basis, usually in a clinical setting and upon payment of the necessary fee. The large masses with communication disorders, for whom successful communication is not a luxury, but a matter of survival, who live far from clinics and other services, are not taken into account. There is an urgent need to bring the service to the people. instead of bringing the people to the service (Uys \& Hugo, 1997:24).

Secondly, the Western model has an inherent feature that makes it alien to Africa: it is disorder-oriented. Communication pathologists are taught to diagnose and treat someone with a specific hearing, speech or language disorder. What the people with a communication disorder in Africa need more than anything else, is the provision of a functional service that includes such functions/tasks as awareness programmes for the general public, prevention programmes, multi-disciplinary consultation, and early intervention. A paradigm shift from disorder-orientation to function-orientation is necessary to meet the demands of Africa (Uys \& Hugo, 1997:24).

As far as the science that forms the basis of this change in the nature of the profession is concerned, the following premise must be upheld: "Africanisation seeks to provide a basis for originality and uniqueness that can contribute meaningfully to global knowledge and civilisation" (Makgoba, 1997:64).

\section{ASPECTS OF AFRICANISATION}

Africanisation does not mean that all existing (Western) influences must summarily be disregarded and that everything with an Africa stamp should indiscriminately be embraced. It would be meaningless to undertake a philosophical migration to one corner of the universe, while the rest of the world is busy integrating! (Madi, 1995). The warning issued by Ann Bernstein during a national forum in February 1998 on the role of universities should therefore be taken into consideration. She says: "If something is working in the university system, understand it, nurture it, preserve it. Destruction will take a few short years: recreating excellence will take generations" (CDE 1998:23).

Against this framework, it is my opinion that the Department of Communication Pathology will have to africanise, both in its essence, and as an inseparable part of the University of Pretoria. What does this africanisation entail, and what is already in place within this transformation process? This question can best be answered against the traditional functional framework of a university: education, research and community service.

\section{AFRICANISATION OF EDUCATION}

The most comprehensive manner in which a philosophical and practical basis for the africanisation of tertiary education can be realised, is to establish the premise of life-long learning on a competence-based foundation. It is therefore important for the Department of Communication Pathology to accept the following statement as the basis of its teaching programmes: "Education is a pathnot a destination and not the accumulation of nuggets of knowledge or repertoire of shills. Competency represents the point along this path where the learner understands the foundation of his or her shills and has internalized appropriate professional values to work independently in normal settings and manage his or her own continued growth" (Chambers, 1993:791). This concept is presented in figure 1.

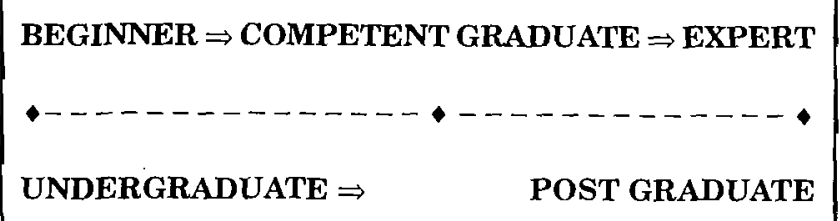

FIGURE 1: Educational Path Of The Lifelong Learner

Undergraduate programmes should be driven by a competency-based curriculum. From figure 1 it is clear that, at undergraduate level this will allow the student to development along the educational road, from beginner to a competent young graduate. It also recognises the importance of postgraduate training, aimed at the eventual crystallisation of a scientific specialist.

This educational philosophy is influenced and structured by a number of 'Africa' trends, only a few of which can be mentioned here.

\section{AFRICANISATION OF EDUCATION AND THE MULTICULTURAL CONTEXT}

In conjunction with the development of an ethical consciousness, which is the most important feature of our modern renaissance, universities worldwide have also come to realise that they are in the midst of a multicultural situation. Various tertiary institutions have attempted to handle this situation in different ways, frequently with a lesser degree of success. One of the most important mistakes that has been made, has been to believe that a department makes provision for multiculturality by adding snippets and pieces of information about different cultures to the curriculum. This can never be more than a cosmetic patchwork process. Another mistake is to accept that people from 'other' cultures have necessarily been educationally and/or culturally deprived, and then to recognise their multiculturality by providing programmes to members of this so-called deprived group, so that they can be 'compensated and/or developed'.

As far as the Department of Communication Pathology is concerned, we believe that we have an advantage because we not only have multicultural student groups and staff, but we are positioned in the reality of a multicultural communication impaired community which functions as a teaching laboratory. In order to ensure the full assimilation of multuculturality the following premises are made:

- Multiculturality forms an inherent component of all our teaching programmes. It can be clearly observed in the important role which modules such as community-based rehabilitation, play in the syllabus. At the microlevel of learning material, it is even more evident in teaching-content that includes: how to work with and through 
interpur(ers; how to identify community needs; how to initiat. lay training for different cultural groups, etc. 'The depirtment, strongly believes: "a curriculum that wherts the cultures, persperetives and histories of ethnir wroups will holp ... students to achieve at higher Irenls brouses students learn best in an educational rnviromment that validates their cultures and is consistent with the ways in which they learn" (Banks, 1986:47).

- The departmental teaching philosophy completely incorporates the aspect of multiculturality. Based on the model of Banks (1986:23), figure 2 is used as a point of departure:

\section{THE MULTICULTURAL PROFESSIONAL AND ACADEMIC CONTEXT}

Department has norms and values which reflect and legitimise ethnic and cultural diversity.

Staff upholds attitudes and value systems based on knowledge and insight in the multicultural composition of the general public, the communication disordered population and the student corps.

Teaching and evaluation of students promotes social and ethnic equality.

Curriculum and teaching material//aboratories are aimed at providing multicultural perspectives, concepts, questions and problems.

\section{FIGURE 2: A Multicultural Teaching Programme}

Source: adapted from Banks 1986:23

- Finally, it is also our conviction that lecturers cannot function successfully within a multicultural context and with ethnically diverse students if they are not well prepared at a professional level to do so. "The degree to which multicultural education becomes a reality in our schools depends largely upon the attitudes and behav. iours of teachers" (Roderiquez, 1983 in Gay, 1986:154).

\section{CHANGES IN HEALTH CARE AND THE IMPLICA- TIONS FOR AFRICANISATION OF EDUCATION}

The africanisation of education in Communication Pathology is closely linked to the related transformation of the health care system of Southern Africa. The most important feature of this is the acceptance of the Alma Ata ideal of 'Health for All by the year 2000', mainly through the application of the policy of primary health care. In essence, primary health care is: "the first level of contact of individuals, the family and community with the national health system, bringing health care as close as possible to where people live and work, and constitutes - the element of a continuing health care process" (Alma Ata, 1995).

Primary health care has certain features that are of particular importance for rehabilitation services - and thus also for the tertiary teaching programmes of the Department of Communication Pathology. The Department of Health emphasises that its objective is to formulate a complete primary health care package, which encompasses the elements of healing, rehabilitation and preventative services. Implicit in this are services such as health education, counselling, community-based rehabilitation, preventative action and the early identification of potential pathology (Department of Health, 1995).

For communication pathologists this means that they can no longer continue along the former road of specialist services in a one-to-one situation within the context of referral/diagnostic hospitals. This is a move away from institution-based services, to providing community-based services, with a much greater emphasis on those tasks of communication pathologists that were previously regarded as being 'secondary', namely education, prevention, consultation and counselling.

The Department of Communication Pathology has already made a paradigm shift with the new undergraduate curriculum which meets all the above-mentioned demands. A curriculum is, however, only a teaching blueprint. In the case of vocational education programmes, the laboratory in which teaching takes place, is of the utmost importance. For this reason the Department is thankful for the opportunity offered by the Department of Health of Mpumalanga to participate in the agreement with UP, and in this way make staff available at the Witbank Hospital, who play an active role in the teaching of students. Here our students can experience health care in the actual situation. The first groups already received their training there in 1998, and the possibility exists that this project may be expanded to the Northern Province during 1999. In conjunction with this, attempts have been made to expand the teaching of community-based rehabilitation with the appointment of Sotho-speaking lecturers, in conjunction with active teaching of community rehabilitation service in areas such as Hammanskraal.

This altered pattern of primary health care and community services also demands that the Department of Communication Pathology develops additional programmes to satisfy the training needs of other (related) specialist services. Programmes such as certificate programmes for community rehabilitation workers, speech and hearing assistants who render area-specific services, interpreters, etc, as well as diploma programmes such as those for hearing aid acoustics, are demands which have been made, and which will have to be met.

\section{AFRICANISATION OF TERTIARY EDUCATION RE- LATED TO CHANGES IN THE SCHOOLS}

The present South African education system is also characterised by transformation, which has important implications for the services communication pathologists are required to provide in the education context. Certainly the most important aspect of this is accepting the fact that the foundation of a quality education for all, is the principle of 'an inclusive learning environment'. For speech-language therapists and audiologists, this means that in the future they will also need to render a service to the child who previously attended a special school, but who has now been incorporated into mainstream education. Some of the important.tasks they will have to fulfil, include:

- participation in early/pre-school programmes with specific focus on the development of communication;

- the provision, development, adaptation and maintenance of assistive devices (hearing aids, communica- 
tion systems) that can help pupils overcome specific barriers to learning;

- overcoming learning inaccessibility. An example of this is the fact that one of the most important features of Curriculum 2005 is its auditory basis. Unfortunately, the traditional school environment is, by the very nature of its facilities (echoing classrooms, hard reverberating floors, glass walls and corridors that distort sound), acoustically largely inaccessible. Here the audiologist has an important consultative role to perform;

- community-based rehabilitation of the schoolgoing child with a communication impairment;

- participation in the development of relevant school curricula in order to make it accessible for pupils with communication disorders (Quality Education for All, 1997).

To perform these tasks, the primary role of communication pathologists within the education system, will have to change. Greater emphasis will have to be placed on the communication pathologist's role as a facilitator and consultant within a transdisciplinary team. One of the important features of the Department of Communication Pathology at the University of Pretoria is that the Department has always been able to function pro-actively and to be an important participator in policy formation. It is therefore not strange that this 'new' role in education is already reflected in the existing activities of the Centre for Early Intervention in Communication Pathology and the Centre for Augmentative and Alternative Communication. From 1999 Kommunika will provide innovative programmes to undergraduate students as well as to other educational professionals in order to ensure that the communication pathologist of the future will be equipped to function successfully as a valuable and appreciated member of the educational team.

The change in the education policy offers the Department an excellent opportunity to participate in transdisciplinary tertiary programmes aimed at the teacher and related professions. The existing diploma developed in conjunction with the Department of Didactics, the Further Diploma in Specialised Teaching (Hearing-Impaired Persons), is an example of the new trends in this niche.

\section{AFRICANISATION OF EDUCATION ASSOCIATED WITH LANGUAGE INFLUENCES}

As far as language is concerned, it is true that Southern Africa is currently, both officially and unofficially, engaged in a veritable confusion of tongues. For the communication pathologist, this situation is a dilemma as well as an opportunity. In the case of most other health professions, language is the medium to rehabilitation, while for the communication pathologist, it is both the medium and the eventual goal. This implies, in the first instance, that there is a great need for communication pathologists who are first-language speakers in all the different African languages, who can provide a meaningful service to the entire communication impaired population. This is an important prescriptive requirement in respect of the student corps of this department.

In the school classroom, language is of exceptional importance if one takes into consideration that it is the 'medium' whereby knowledge is conveyed. As a result of the changing education policy, there are increasingly larger groups of children in schools today for whom the teaching medium is strange and who, due to their language incapabilities, require intervention. The communication pathologist of the future must therefore be much better equipped than in the past to participate in support programmes to non-first language speakers in the schools, as well as to make a contribution to the development of second language teaching programmes.

A final aspect concerning language that should receive attention, is the Sign Language of the Deaf. As has already been stated, the audiologist is the professional who is mainly involved with individuals and groups of people who have suffered a loss of hearing, and the audiologist is primarily responsible for offering support in respect of their communication. A section of this population are the Deaf, who have accepted South African Sign Language as their first language. It is therefore important that the audiologist should be proficient in this language, in order to play a role in developing the skill of people who wish to acquire this language.

\section{AFRICANISATIONOF EDUCATIONAND TECHNOL- OGY}

There is irrefutable proof that technology will probably be the channel through which economic and social growth will take place in the next millennium. This is true for the professional functioning of communication pathologists worldwide. The question is - what is the relation between the africanisation of education at universities on the one hand, and technology on the other? While compiling a research policy for higher education in South Africa, Whiston came to the conclusion that South Africa is not exclusively a first (high technology) or a third world country, but rather "different worlds in one" (Whiston, 1995:11). In order to cope with this ambivalence he proposes that "South Africa has to appreciate that it is part of Africa, and that it has experience and knowledge to share but it has much also to learn from other societies. It should see itself as a participant in joint ventures in science and technology on the continent ..." (Whiston, 1995:224). In the practical situation this can be ensured by bringing the operational and maintenance demands of new technology in line with the skills and knowledge of the community that is going to use the technology (Serpelke \& Nabletzol, 1991).

It is the task of the Department of Communication Pathology to give shape to the abovementioned proposal: to make Africa technologically accessible to individuals with communication disorders, and to ensure that the value and benefits of technological developments do not pass by the Africa-impaired. In this way, Communication Pathology can contribute to an improved quality of life. Technology that is already incorporated in the education programmes at the Department of Communication Pathology includes cochlear implants and digital hearing aids for severely hearing impaired persons, as well as the use of computerised communication systems for the severely physically handicapped.

\section{AFRICANISATION OF RESEARCH IN COMMUNICA- TION PATHOLOGY}

A science is nourished by the research that generates it. For this reason it is unacceptable to believe that the africanisation of research would in reality mean that no research should be conducted. Proponents of this idea, such 
as Fyle (1985), argue that research is a luxury that African countries cannot afford, and that the dissemination of research information is the best that they should be capable of. In contrast to this, I maintain that research must be seen as the cornerstone upon which the africanisation of education can be developed.

However, this research must be characterised by innovation in order to satisfy the demands of Africa. The following are a few proposals to achieve this innovation:

- According to Whiston (1995) researchers have the specific ethical responsibility to execute relevant and effective research. This means that research must be socially justifiable and relevant to the context. The field of communication, as the medium and eventual aim of human social existence, lends itself pre-eminently to such research.

- In conjunction with this, the generation of multi-disciplinary and transdisciplinary research is becoming all the more important - a demand that is particularly applicable and acceptable to the humanities, because their primary research subject is man in all his facets (Voster, 1995).

- The Commission on Health Research for Development identifies research as the process whereby equality of development can be achieved. They also request that research in the field of essential health aspects should be given preference. Once again, this is an area in which the Department of Communication Pathology can and will make a contribution. A study of the departmental annual reports of the last decade indicates that the Department has already contributed to this research area by conducting research on topics such as: the provision of habilitation services in rural areas; the occurrence and implications of specific African diseases, such as malaria, for communication pathology; noise pollution and hearing protection in industries such as the gold mines, etc.

- Given the nature of Africa, and in conjunction with the demands of justifiable and relevant research, the dissemination of research results is becoming all the more important. This specifically does not mean that research should at the conclusion be wrapped up in an article package and presented to other specialists in a learned debate. On the contrary, it implies that departmental research should adapt a research philosophy that includes dissemination as an inherent component of the total process. The foundation of this viewpoint is contained in the following figure:
Figure 3 clearly indicates that research does not take place in a vacuum, but in collaboration with a 'research associate', which can be an individual/group/entity and which has a shared responsibility for the entire process. The researcher has the greatest responsibility for carrying out research (but he does not bear this responsibility alone). The associate, in contrast, has the greatest responsibility for the implementation and acceptance of the research results - the eventual and greatest aim of dissemination. With such a research philosophy incorporated in the departmental mission it must be accepted that research in the Department of Communication Pathology has made much progress along the road of africanisation.

\section{AFRICANISATION AND COMMUNITY SERVICE}

The responsibilities of a university are generally acknowledged as being threefold: teaching, research and community service. Of these three, the latter is commonly seen as the 'Cinderella' and is sometimes regarded by academics as a last ditch attempt by universities to "leave their ivory tower and reach out to the community" - often with a secondary motive of financial gain linked to the attempt. Yet, it cannot be denied that it is precisely the community that plays such an important role in academic life: it identifies general teaching objectives, influences the curriculum and sets priorities for teaching and research (Altman, 1996).

The University of Pretoria is defined as being a community-based institution that has a social responsibility to place its knowledge and skills at the disposal of the community. This role is clearly spelled out in its mission statement, and realised in the establishment of structures such as the Centre for Reconstruction and Development (Audit Portfolio, 1997). It is also significant that statements such as the following were made in UP's annual review of 1997: "Departments that launch community service projects increasingly find innovative ways of integrating such projects in their teaching and research agendas"(UP Annual Report, 1997:5).

However, the abovementioned attitude is not sufficient for true africanisation. Universities and Departments should not render a service to communities -- in that way they will never become part of the community. Rather they should be involved in the community - and this involvement must be a symbiotic process. A department may not merely offer skills and expertise to the community in a one-way relationship (which also contains a quality of "I'm OK - you're not OK" in such a relationship). The depart-

\begin{tabular}{|l|l|l|l|l|l|}
\hline $100 \%$ & & & & & \\
\hline $80 \%$ & & & \multicolumn{3}{|c|}{ ASSOCIATE RESPONSIBILITY } \\
\hline $60 \%$ & & & & & \\
\hline $40 \%$ & & & & & \\
\hline $20 \%$ & & & & & \\
\hline $0 \%$ & & & & & \\
\hline
\end{tabular}

FIGURE 3: Participative Research

Source: Powell et al., 1989. and Uys \& Hugo, 1997 
ment must also be receptive to receive input like skills and expertise from the community. In this way departmental education and research programmes are not only initiated, but the nature and quality of these programmes are driven by the community. The result of this is that the department can then comply with one of the most important demands tertiary education has to face today - that of relevance in its curriculum and areas of research expertise.

Such a viewpoint necessarily means that community involvement will play a much greater role in the functioning of a department than is generally recognised or accepted. This has also important implications for aspects such as subsidy formulae and staff-student ratios. In the Department of Communication Pathology, this principle has for years been accepted, and is reinforced through the existence of units such as the Speech, Voice and Hearing Clinic, the Centre for Augmentative and Alternative Communication, the Centre for Early Intervention in Communication Pathology, CHRIB and Kommunika. There are, however, still important gaps, that must be filled in order to ensure that these structures satisfy the demands of an African community.

\section{IN CONCLUSION}

I am privileged to be an academic - to be able to contribute to the development of the youth of today and South Africa's future. Privileges may, however, not be summarily claimed. Privileges are linked to responsibilities. One of these responsibilities is adaptability. In the 1997 annual review of the University of Pretoria, the principal declares that Universities throughout the world must adapt to changes in the market place (Van Zyl, 1997:4). Programmes for professional education and training are responsible for taking a very specific sector of the market place as their point of departure: the community that is served by the profession. For speech-language therapists and audiologists who have received and are receiving their training at the University of Pretoria, this population is irrefutably the communication impaired African.
I therefore believe that the only way forward for the Department of Communication Pathology runs through the Heart of Africa.

\section{REFERENCES}

Altman, I. (1996). Higher Education and Psychology in the Millennium. American Psychologist, 51 (4) :371-378.

Audit portfolio, UP.

Banks, J A. (1986). In Banks, J A \& Lynch, J. (eds). Multicultural education in Western societies. London: Holt Rhinehart \& Winston.

CDE Round Table, no 2. (1998). The Centre for Development and Enterprise, Johannesburg.

Chambers, D W. (1993). The challenges of modularization. Innovations in Education and Training International, 32 (2): $96-105$

Cilliers, G. (1980). 'n Beroepstudie van spraakterapeute en oudioloë. HSRC report no MM79.

Department of Health Annual Report, 1995.

Gay, G. (1986). Multicultural teacher education. In Banks, J A \& Lynch, J. (eds). Multicultural education in Western societies. London: Holt Rhinehart \& Winston.

Madi, P. (1995). Moving the Centre. People Dynamics. March:1216.

Makgoba, W. (1996). South African universities in transformation: Africanise or perish. Politica, 15 (2):114-118.

Nigga, C. (1997) Trends in Health and Health Care in South Africa. In Lemon, A (Ed) The Geography of Change in South Africa.

Seagraves, S. (1996), A Campus of Our Own. Change, March/April, pp 153-160.

Sono, T. (1996). Do African universities need an African ethic? Politica $15(2): 119-121$

Quality Education for All. (1997). Report of NCSNET \& NCESS, Department of Education.

Uys, I C. (1993). Kommunikasiepatologie: onderrig vir die toekoms. Inaugural address, University of Pretoria.

Uys, I \& Hugo, R. (1997). Speech-language pathology and audiology: transformation in teaching, research and service delivery. Health SA Gesondheid, 2 (2):23-29.

Van Zyl, J (1997). Overview by the Vice-chancellor and Principal. University of Pretoria Annual Review 1997.

Voster, P J. (1995). Africanisation: an explanation and some educational implications. South African Journal of Education. 1995,15 (1) : 6-12

Whiston, T G. (1995). Research policy in the higher education sector of South Africa. FRD. 